\title{
Toplumsal Hareketlenmede Önemli Bir Durak: Sosyal Ağlarda Dijital Aktivizm ve Dinamiklerine İlişkin Y ve Z Kuşağının Farkındalıkları Üzerine Bir Araştırma
}

DOI: 10.26466/opus.665241

\author{
Gonca Köse* \\ * Öğr. Gör. Dr., Dokuz Eylül Üniversitesi, Bergama MYO, Bergama/İzmir/Türkiye \\ E-Posta: gonca.dogru@deu.edu.tr \\ ORCID: $0000-0001-6464-4014$
}

Öz

Dijital teknolojiler aracılığıyla insan ve dijital dünyanın etkileşimi artmış, dijital araçlar gündelik hayatımızın her anına nüfuz etmiştir. Özellikle $Y$ ve $Z$ kuşă̆ının dijital platformlarla büyümeleri ve olgunlaşmaları; her konuya, duruma, olguya ilişkin yüksek ilgi ve merakları sosyal medya ve araçlarındaki rollerini daha etkin hale getirmiştir. Öyle ki dijital dönemin; kuşakların karakteristik özellikleri üzerindeki belirleyici etkisi de göz ardı edilememektedir. Dijital platformlarda toplumsal hareket kapsamına giren ekonomik, sosyal, çevresel, politik vb. konulara ilişkin fikir ve düşüncelerini paylaşma, kendini ifade etme isteği dijital aktivizm olgusunu gün yüzüne çıkarmış ve kuşakların dijital aktivizm hakkında bilgileri, görüşleri ve tutumları son derece önemli hale gelmiştir. Bu bağlamda çalışmanın amacı; dijital odaklı yaşayan, sosyal medya ve araçlarının öncelikli kullanıcılarından $Y$ ve Z kuşă̆ının dijital aktivizm hakkındaki farkındalıkları; bilgileri, bakış açıları, düşünce biçimleri, ilgileri, anlayış ve yorumlama düzeylerini tespit etmektir. Çalışmada nicel araştırma yöntemi kullanılmıştır. Veri toplama aracı olarak anket formu hazırlanmış ve anket $Y$ ve $Z$ kuşaklarına uygulanmıştır. $Y$ ve $Z$ kuşağından oluşan toplam 148 katılımonın verileri SPSS Windows 25.0 programına aktarılarak analiz edilmiştir. Veriler, anlamlılık $p<0,05$ düzeyinde değerlendirilmiştir. Nicel değişkenlerin analizi için Mann Whitney U testi kullanılmıştır. Kategorik değişkenler arasındaki ilişkiyi analiz edebilmek için Pearson Ki kare analizi yapılmıştır. Z kuşağııın, Y kuşă̆ından daha fazla sosyal ă̆larda vakit geçirdiği; kuşakların sosyal ağları gündelik hayatlarında yaptıklarını detaylı paylaşmak ya da komik ve eğlenceli içerikleri bulmak dışında; dijital aktivizm kapsaminda sosyal ă̆ları; bir ideoloji veya toplumsal hareketi desteklemek amaçlı da kullandıkları sonucuna varılmıştır.

Anahtar Kelimeler: Dijital aktivizm, toplumsal hareketlenme, y kuşağı, z kuşă̆ı, sosyal ăg 


\title{
A Significant Destination in Social Activation: A Research on Awareness of $Y$ and $Z$ Generation Regarding Digital Activism and Its Dynamics in Social Networks
}

\begin{abstract}
The interaction of human and digital world has increased through digital technologies and digital means have penetrated into any moments of our daily life. Since especially $Y$ and $Z$ generations have grown and developed with the digital platforms; their high interest and curiosity related to every subject, circumstance, and fact have made their roles in social media and its means become more efficient. Such that, the determinative effect of digital period on characteristic features of the generations cannot be denied. Sharing opinion and ideas regarding issues such as economic, social, environmental, politic etc. within the scope of social activity in digital platforms and the will of self-expression have brought the fact of digital activism to light and the knowledge, views and attitudes of the generations on digital activism have become extremely significant. In this context, the goal of the research is to determine the levels of awareness, knowledge, views, way of thinking, interests, approaches and commenting of the $Y$ and $Z$ generation who live digitally oriented and whom are primarily users of social media and its means related to digital activism. The quantitative research method was used in the research. Questionnaire form was prepared as data acquisition tool and the questionnaire was applied to $Y$ and $Z$ generations. The data of 148 participants consisting of $Y$ and $Z$ generations in total was analysed by transferring to SPSS Windows 25.0 program. The data was evaluated at level of significance $p<0,05$. Mann Whitney $U$ test was used in order for analysis of quantitative variables. Pearson Ki square analysis was applied in order to analyse relationship between categorical variables. It was concluded that $Z$ generation spare time in social networks more than Y generation; they use social networks in order to support an ideology or social movement within the scope of digital activism except for using social networks for sharing what they did in their daily lives or searching for comic and funny contents.
\end{abstract}

Keywords: Digital activism, social activation, y generation, z generation, social network 


\section{Giriş}

Tarih boyunca toplumsal yaşamda çarpıcı değişimlerin temel taşıyıcısı teknolojik yenilikler olmuştur. Bilgi iletişim teknolojilerinin gelişimi; bilgisayara ve iletişim araçlarına bağlı bir yaşam tarzının benimsenmesini beraberinde getirmiştir. Söz konusu yaşam tarzının içselleştirilmesinde mihenk taşı olarak görülen internet ise; dijital devrimin yegane öncüsü olmuştur. Internet'in anlamının ve bunun sonucunda pratiklerinin; zaman ve mekandan bağımsızlığı; insanların dünya üzerinde olup biten her olay ve durumdan en hızlı biçimde haberdar olmalarını sağlamaktadır. Dolayısıyla zamanın en büyük ve en önemli buluşlarından biri olarak kabul edilen internet; yeni bir toplumsal düzene yelken açmıştır. Sosyal medya da internetin gelişimi ile yeni bir oluşum olarak dijital devrimin öncüllerinden biridir. Günlük yaşamın sanal ortamlara taşındığı, her şeye dijitalin bulaştığı bir çağda; toplumsal hareketler de bu durumdan nasibini almıştır. İnsan, hayvan, çevre hakları vb. toplumu doğrudan ilgilendiren konularla ilgili olarak insanların belli bir amaç etrafında birleşmesini temsil eden toplumsal hareket kavramının kökeninde bugün artık dijital platformlarda yaratılmaya çalışılan kolektif tutum ve davranışlar yatmaktadır. Toplumsal hareket kavramı ile ilişkilendirilen aktivizm kavramı ise artık yerini dijital aktivizme bırakmıştır. Dijital aktivizm; çeşitli iletişim teknolojileri aracılığıyla dijital ortamlarda kişileri harekete geçirecek aktivist söylem ve eylemlerde bulunmaktır. Öyle ki dijital aktivizm kavramı ile en fazla özdeşleştirilen, dijitalleşmeyi en derinden yaşayan kuşak ise şüphesiz teknoloji kuşağı olarak kabul edilen y kuşağı ile dijital çağın dinamiklerini iliklerine kadar yaşayan, dijital yerli olarak da adlandırılan z kuşağıdır. Bu bağlamda çalışmanın ilk bölümünde; aktivizm, dijital aktivizm, toplumsal hareket kavramları açıklanacaktır. Ardından y ve z kuşağının dijital aktivizm hakkındaki bilgi düzeylerini ortaya koymak, kavrama ilişkin farkındalıklarını tespit etmek amacıyla niceliksel bir araştırmayı yer verilecektir. Son olarak da elde edilen niceliksel verilerden hareketle y ve z kuşaklarının; dijital aktivizm hakkında kendilerini nasıl değerlendirdiklerine dair yorumlar karşılaştırmalı olarak aktarılmaya çalışılacaktır. 


\section{Eskiden Yeniye Evrilen Toplumsal Hareketlenme Kavramı}

İnsanoğlunun; varoluşundan bu yana ekonomik, sosyal ve çevresel birçok konuyla ilgili yaşadıkları kolektif sorunlar karşısında hak ve adaleti arama mücadeleleri devam etmiştir. Özellikle endüstrileşme, teknolojik devrimler, internetin artan gücü ve gündelik yaşama olan derin etkisi gibi nedenler sonucunda değişime uğrayan toplumsal yapı içerisinde insanlar; söz konusu değişimlere çeşitli ölçülerde karşılık vermişlerdir. Değişimlere; direnç gösterme, kolektif mücadele, ayaklanma şeklinde verilen karşlıklar zaman içerisinde etkisini artırmıştır. Zira sanayileşmenin, kapitalist toplum yapısının ve ekonomik düzenin belirleyiciliği karşısında ortaya çıan adaletsizlik, haksızlık, eşitsizlik gibi olgular toplumsal hareket kavramina odaklanmayı beraberinde getirmiştir.

Toplumsal hareketlerin tarihine bakıldığında ilk olarak 19. yüzyılda yaşanan kapitalizme bir tepki şeklinde ortaya çıkmış, modern toplumun gelişmesi ve sanayileşmenin artmasıyla artan sosyal adaletsizliğe bir karşı duruş biçiminde kendini göstermiş ama "Toplumsal hareket" kavramı ilk kez Batı Avrupa ülkelerinde işçi hareketleriyle kullanılmaya başlanmıştır (Işık, 2015, s.17). Lorenz Van Stein; tarihte toplumsal hareket kavramını halkın politik mücadelesi bağlamında ilk kullanan isim olarak kabul edilmektedir (Tilly, 2008, s.20). Sosyal hareket olarak da literatürde yerini alan toplumsal hareket kavramı tarihsel süreç içerisinde; dönemin şartlarına bağlı olarak farklı şekillerde tanımlanmıştır. Touraine'e göre (1999, s.51) toplumsal hareket; bir sosyal hareket, tarihselliğin biçimi, kültürel yatırım, bilgi ve ahlak modelleri üzerindeki hakimiyeti ya da bağımlılığı ile tanımlanan bir sosyal sınıfın, bu kültürel modellere yönelmiş çatışmacı hareketidir.

Toplumsal hareketler geleneksel olarak toplumsal değişimi ortaya çıkarmak için verilen örgütlü çabalar olarak tanımlanmışlardır (Form ve Craig, 2013, s. 419). Örgütlü toplumsal hareketlerin birinci özelliği, “kolektif meydan okumak" (hem tartışmacı hem de uzlaşımcı kolektif eylem yoluyla kurumsal düzenlemeleri değiştirme çabaları); ikinci özelliği de, siyasi bir karaktere sahip olmasıdır (Form ve Craig, 2013, s.421). Sistem karşıtı hareketler (C,oban, 2009, s.177) kavramı olarak da tanımlanan toplumsal hareketin doğuşu Charles Tilly'e göre üç unsurun sentezinden oluşmaktadır (Tilly, 2008, s.17): 
- Hedef alınan otoritelere karşı yapılan ortak hak talebi kampanyaları,

- Çeşitli siyasi eylemlerin gerçekleştirilmesi. Bu tür eylemler; özel kuruluş dernekleri kurmak, halk toplantıları düzenlemek, resmi makamlar, gösteriler yapmak, medyaya açılama yapmaktır.

- Halkla uyum içinde; makul olma, birlik, sayı ve kendilerine veya seçmenlerine bağlılık ilkelerini sergilemektir.

Bir başka tanıma göre toplumsal hareketler; elitlere, otoritelere, başka gruplara ya da kültürel kodlara karşı, elitler, diğer gruplar ve unsurlarla kalıcı bir etkileşim içinde, ortak hedeflere sahip ve dayanışma içinde olan bireyler tarafından geliştirilen toplu eylemler" olarak tanımlanmaktadır (Tarrow'dan aktaran Demiroğlu, 2014, s.135). Dayanışmaya dayalı, bir çatışma taşıyan ve yer aldığı sistemin sınırlarını zorlayan bir kolektif hareket biçimi (Melucci, 2016, s.81) olan toplumsal hareket; yerleşik alanın dışındaki toplu eylemler yoluyla, ortak bir çıarı korumak ya da ortak bir hedefe erişmeyi sağlayabilmek için girişilen toplu bir çaba olarak da kabul edilmektedir (Giddens, 2000, s.540-541). Toplumsal hareketler, birinci ve ikinci dalga, eski-yeni, klasik ve yeni sosyal hareketler olarak adlandırılmaktadır. 19. yüzyılın ikinci yarısından 1990"lara kadar uzanan süreç şu şekilde nitelendirilmektedir (Çımrın, 2010, s.2):

- Eski Toplumsal Hareketler; İşçi Sınıfı Hareketleri ve Ulusal Kurtuluş Mücadeleleri.

- Yeni Sosyal/toplumsal Hareketler; feminist, çevreci, savaş karşıtı hareketler vb.

Yeni toplumsal hareketler genel olarak "endüstriyel toplumdan" "postendüstriyel topluma", "örgütlü kapitalizm" den "örgütsüz kapitalizm" e geçişin sonucu olarak ortaya çıkmış, geçmişin nesnel sınıf çıarlarına dayalı olarak hareket eden işçi sınıfı hareketlerine karşılık, merkezine dağıtım meseleleri yerine kültür, kimlik, özerklik, nitelikli yaşam meselelerini koyan hareketler olarak ele alınmaktadır. Bu hareketlerin protestonun yeni bir biçimini sundukları ve ileri endüstriyel toplumun özelliklerini yansıttıkları ileri sürülmektedir (Coşkun, 2007, s.134-135). Yeni toplumsal hareket denildiğinde; adın hareketi veya feminizm, işçi ve sendika hareketleri, faşist hareketler, faşizme ve ırkçılığa karşı hareketler, çevreci, milliyetçi, hayvan hakları vb. olgular dikkat çekmektedir (Crossley, 2002, s.1). Çoban'a göre; feminist, rrkçılık, cinsiyetçilik 
karşıtı vb. mücadeleyi ve demokrasiyi esas alan yeni toplumsal hareketler ile sınıf mücadelesinden doğan eski toplumsal hareketler arasındaki temel fark şöyledir: yeni toplumsal hareketlerde; hedef, antagonizmayı (cinsiyetlerin, dinlerin, etnik grupların "huzurlu" bir arada olmaları) farklılığa çevirmek iken, eski toplumsal hareketlerde hedef tam tersidir. Sınıf farkını sınıf antagonizmasına doğru şiddetlendirmeyi amaçlar. Bu bağlamda yeni toplumsal hareketler çözümlemeye çalıştıkları sorunu çözmek adına sistem içi araçlara başvurup var olan yapı içerisinde yeni bir açılımı zorlarken, sınıf hareketi tersi bir biçimde istediği sistemi hayata geçirmek için mevcut sistemi parçalamayı hedef alır (Çoban, 2009, s.31). Öte yandan Pakulski'e göre eski ve yeni toplumsal hareketler üç temel noktada farklılaşmaktadır: Bunlardan ilki jenerasyondur ve bugünkü hareketlerin gençleri kapsadığı gerçeğidir ve jenerasyon kavramı sınıf kavramına göre daha açıklayıcıdır. İkincisi statü politikaları denen, eski işçi-burjuva çatışmasının yerini statü grupları arasındaki çatışmaya bırakması anlamına gelmektedir. Son büyük fark ise, sivil toplum kavramıdır. Çünkü yeni toplumsal hareketler sosyalist bir devrimi amaçlamayan, devletin değil sivil toplumun egemen olduğu, hareketin merkezini siyasal değil sosyo-kültürel yapının belirlediği hareketlerdir (Çayır, 2016, s.61).

Eski toplumsal hareketlerden, yeni toplumsal hareketlere doğru gerçekleşen dönüşümün; kuşkusuz yeni iletişim ve enformasyon teknolojilerindeki gelişmelerle ilişkisi göz ardı edilememektedir. Bu noktada ise; internetin gelişimi sayesinde gazete, dergi, televizyon gibi geleneksel medya araçları, yerini yeni medya teknolojilerinden özellikle sosyal ağlara bırakmıştır. Dolayısıyla bu durum geleneksel medyada üretilen içeriklerle sınırlı kalmamayı; bireylerin ses, yazı, video vb. formattaki içerikleri üretebilmelerini, sosyal ağlar aracilığıyla her türlü enformasyona ulaşabilmelerini kolaylaştırmaktadır. Sınırsız bilginin, belgenin ve anlık paylaşımların yapıldığı sosyal ağlarda enformasyonun zamansızlığı ve bolluk prensibiyle birlikte dünyanın pek çok bölgesinden aynı fikri savunan, benzer mental yapılara sahip bireyler, sanal ortamda bir araya gelebilmekte ve sinerji yaratabilmektedirler. Bu bağlamda yeni toplumsal hareketlerin hem çıkış noktası hem de itici gücü şüphesiz dijital aktivizm olmuştur. 


\section{Dijital Aktivizm ve Türleri}

Dijital aktivizme geçmeden önce; tarihsel uzantısı esasında çok eski olan aktivizm kavramına kısaca değinmekte fayda görülmektedir. Aktivizm yaşanan toplumsal dönüşümlere destek olarak ya da karşı çıkarak ortaya konan davranışlar (Turhan ve Okcu, 2018, s.183); toplumda ilerleme kaydetmek ve toplumu dönüştürmek maksadıyla gösterilen çabaların tamamı olarak tanımlanabilir (Shaw, 1996). Eylemcilik ya da etkincilik olarak da kavramsallaştırılan aktivizm; Kim ve Sriramesh gönüllü olarak örgütlenmiş bir grup insanın ortak çıkarları tehdit eden bir problemi çözebilmek için gösterdikleri koordineli çabalar (Sert, 2012, s.128) olarak tanımlamaktadırlar.

Dolayısıyla aktivizm tanımları incelendiğinde; aktivizmi toplumsal düzlemde değişim yaratmayı hedefleyen ve bu hedefe uygun olarak gerçekleştirilen eylemlerin bütünü olarak özetlemek; bu eylemlerin aktörlerini de aktivist olarak değerlendirmek mümkündür. Aktivizm; küresel düzeyde yaşanan değişimler, teknolojik devrimler, zaman ve mekan engelini ortadan kaldıran internet aracılığı ile köklü değişimler yaşamış ve yerini önemli ölçüde dijital aktivizme bırakmıştır. Internet'in büyüleyici etkisiyle de yeni toplumsal hareketlerin kök salması neticesinde dijital aktivizm kavramı yeni ve derin anlamlar kazanmıştır. Gladwell'in de belirttiği gibi internet, atomize haldeki bireyler yerine, daha iyi organize olmuş halk örgütlenmeleri tarafından kullanıldığında etkili bir siyasi değişim aracı haline gelebilmektedir (Morozov, 2017, s.23-24). Bu bağlamda Uçkan'a göre (2012) dijital aktivizm; farklı aktivizm türlerinin internet ortamında kullanılmasına verilen genel bir ad; dijital platformda kullanılan her türlü aktivizm örneğidir (Sivitanides, 2011, s.2). Bireylerin veya toplulukların, ağ yapıları ve bilgi teknolojilerinin hızlı yayılım niteliklerinden faydalanarak, savundukları ya da tepki gösterdikleri, ifade özgürlüğü, insan hakları ya da çevre gibi sosyal veya politik konulardaki dava veyahut olaylar üzerine merkezden bağımsız büyüyebilen, temel amacı yüksek kamuoyu sesi üretebilmek olan eylemle tasarlayarak ortaya koyması dijital aktivizm olarak ifade edilmektedir (Kırık ve Özcan, 2014, s.66). Toplumsal hareketler bağlamında yeni medya araçlarının kullanımı, diğer bir ifadeyle dijital aktivizm, hem sokaktaki faaliyetleri örgütlemek adına bir iletişim kanalı olarak hem de doğrudan ortamın kendisiyle 
sınırlı faaliyetler biçiminde karşımıza çıkmaktadır (Uçkan'dan aktaran Çayır, 2018, s.56). Internet aktivizmi, e-aktivizm, siber aktivizm, online aktivizm olarak da adlandırılan dijital aktivizm; belli bir amacın savunusu, bu amaç etrafında veya belirli bir eylemi gerçekleştirmek için örgütlenme, amaca yönelik mesajları bir iletişim kampanyası çerçevesinde kitlelere iletme, amaç doğrultusunda lobi faaliyetleri gerçekleştirme, internet üzerinde eylem gerçekleştirme (boykot, site karartma vb.), amaca yönelik kaynak toplama / fon oluşturma, hükümetler veya şirketlerin faaliyetlerini izleyerek düzenli olarak raporlama (watchdog) gibi temel aktivist faaliyetlerin, başta sosyal medya olmak üzere geniş kitlelere gerçek zamanlı bilgi akışı ile ulaşmaya imkan tanıyan alanlarda veya blog, vlog, podcast, video, fotoğraf paylaşım siteleri gibi alanlarda gerçekleştirilmesi" anlamına gelmektedir (Uçkan, 2012).

Dijital aktivizmin; slaktivizm, klicktivizm, hacktivizm vb. biçimleri bulunmakta ve bireylerin yeni iletişim teknolojiler sayesinde, aktivist faaliyetleri çok hızlı, etkili, çok sesli, eşzamanlı ve ulaşılabilir bir şekilde gerçekleştirebilmektedir. İletişimin ve internet teknolojilerinin hızla gelişmesi aynı zamanda aktivizmin kavramını da değiştirmiş ve hedef kitlenin gerçek medyadan dijital medyaya geçmesi, aktivistlerin bir konuyla ilgili yapılacak eylemlere eşzamanlı ve hızlı bir şekilde ulaşmasını mümkün kılmıştır (Yeğen, 2014, s.121). Dijital aktivizm kavramı üzerine çalışmaya başlayan ilk isimlerden biri olan Mary Joyce dijital aktivizmden bahsedebilmek için bazı temel gerekliliklerden bahsetmektedir. Bunlar; teknolojik altyapı, sosyal, siyasal ve ekonomik faktörlerdir (Joyce, 2010, s.2).

Dijital aktivizmle ilgili yeni medyanın rolünün ne olduğu ve aktivistler tarafından nasıl kullanıldığına ilişkin Morozov'un (2007) görüşleri ise şöyledir:

- Bilgi erişimini ve niteliğini arttırmak

- Kamunun dikkatini belirli bir soruna çekmek

- Gönüllülerin yardımıyla veya toplulukların gücüyle toplanmayı kolaylaştırmak.

- Politikacilar ve seçmenler ile doğrudan temas kurmak

- Sosyal yardımı geliştirmek/yeni üyeler çekmek

- Hareketi seferber etmek ve lojistik konusunda yardım

- Fon toplama ve toplu eylem için yeni ve yaratıcı yollar yaratmak 
- Diğer STK ve aktivistlerle bilgi akışının sağlanması ve yayınlanmasi

Dolayısıyla yeni medyanın büyülü etkisiyle; olaylara, durumlara, olgulara eş zamanlı müdahale etme, talepte bulunma, tepki gösterme hız1nın ve sınır tanımazlığın gücü; dijital aktivizmin dijital ortamlardaki toplumsal etkileşimi perçinlediğini ifade etmek doğru olacaktır. Dijital aktivizm; insana, çevreye, hayvana, gezegene odaklı bir duruş sergileyen, değer üreten, sosyal bilinci artırmayı hedef alan bir nitelik taşımaktadır. Dijital aktivistler de yeni medya araçlarında kendi kimlikleri ve değerleri ile örtüşen sosyal, politik, ekonomik ve çevresel konulardaki görüşlerini paylaşan, kolektif faydayı amaçlayan, bu amaçlar doğrultusunda fikir birliği ve eylem birliği yaratmaya çalışmaktadırlar. Bu nedenle dijital aktivizmin yeni medya kapsamında kitlesel stratejik bir iletişim pratiği olduğunu belirtmek mümkündür.

Dijital aktivizm; amaca uygun seçilebilecek türlere sahiptir. Bunlar; taraf olma/farkındalık aktivizmi, kliktivizm/slaktivizm, hacktivizm, vatandaş gazeteciliği oluşturmaktır. Bunlar şu ana kadar dijital aktivizm türü olarak sınıflandırılmış kavramlardır. Ancak teknolojik gelişmeler devam ettikçe, yeni dijital platformların ortaya çıkması kaçınılmaz olacağı için dijital aktivizm türlerinin de zaman içerisinde artacağı öngörülmektedir. Bu bağlamda çalışma kapsamında dijital aktivizm türlerine kısaca değinmekte fayda görülmektedir (Okcu, 2016, s.147):

- Taraf Olma/Farkındalık Aktivizmi (Advocacy): Taraf olma olarak adlandırılan aktivizm türü sosyal sistem içinde kurumların ya da kişilerin kararlarını etkilemek için bireysel ya da grup olarak yapılan her türlü aktiviteyi kapsar. İnsanlar fikirlerini duyurmak, farkındalık yaratmak, haklarını korumak ve tehdit olarak algıladıkları şeylerden kaçınmak için taraf olma tarzı aktivist hareket girişimleridir. Bu aktivizm türü son dönemlerde "hashtag aktivizmi" olarak daha çok anılmaktadır.

- Slaktivizm/Kliktivizm: İlk olarak 1995 yılında Dwight Ozard ve Fred Clark tarafindan kullanılan slaktivizm kavramının en net tanımı ile "dijital bir eylemi durduğu yerden destekleme" anlamındadır. "Slacker' kelimesi ile "activism" kelimelerinin birleşerek oluşturduğu bu kavram miskin eylemcilik olarak da tanımlanırken, onu icra eden 
kişilere de slaktivistler yani "miskin eylemciler" denmektedir (Yeğen, 2015, s. 90). Dijital aktivizme yönelik eleştirel yaklaşımların başında slaktivizm gelmektedir; çünkü slaktivizmin insanları aktivizme değil pasifizme ittiği iddia edilmektedir. Bir konuda vicdanını rahatlatmak adına insanların online ortamlarda tepkilerini kolay yoldan gösterdikleri, böylece içlerindeki sosyal değişim isteğinin köreldiği düşünülmektedir.

- Hacktivizm: Hacktivizm, kökeni itibariyle hack ve aktivizm kavramlarının bileşimi ile oluşmaktadır (Ruffin, 2004). Hacktivizme ilişkin ilk teorik temel ise Florida merkezli olarak 1987 yılında kurulan Critical Art Ensemble (CAE, Eleştirel Sanat Topluluğu) adındaki sanat, eleştirel teori ve siyasal aktivizmin kesiştiği noktaları keşfetme amacı taşıyan bir topluluk tarafından ortaya koyulmuştur (Boschele ve Öztürk, 2017, s.443). Krapp'a göre (2005); hacktivizmi "politik amaçları gerçekleştirmek adına bilgisayar ve dijital ağların otoriteyi rahatsız edecek şekilde kullanılması" olarak tanımlamıştır.

- Vatandaş Gazeteciliği (Citizen Journalism): Vatandaş gazeteciliği, medyanın mevcut yapısına bir refleks olarak gelişen, iyi niyetli ve reformcu nitelikleri taşıyan bir gazetecilik türü olarak irdelenebilmektedir (Duran, 2003, s. 89). Vatandaş gazeteciliğii, sivil vatandaşların haber ve bilgi toplanmasında, raporlanmasında, analiz edilmesinde ve yayılmasında aktif rol oynaması anlamina gelen bir kavramdır. (Browman ve Willis 2003). Vatandaşların eğitilebilmeleri için gereksinim duydukları konular ile güncel olaylar hakkında haberler üretmeyi, şehir ve yurttaşlık ile ilgili kararlar alınmasını, buna yönelik olarak diyalog ve faaliyetlerin sağlanmasını ve demokrasi anlayışı içerisinde vatandaşların sorumluluklarını harekete geçirerek geliştirmeyi hedeflemektedir (Shaffer, 2004).

Buraya kadar ki bilgiler ışığında yüzyılın buluşu olarak kabul gören internet, buna bağlı olarak başkalaşım geçiren medya ve medyada yer alan sınırsız enformasyon dijital aktivizm kavramının yegane unsurları haline gelmiştir. Dünyada sosyal, çevresel ve ekonomik konular hakkında dijital ortamlarda değişim yaratma mücadelesi güden dijital aktivizmin temsilleri dijital aktivistler yeni medya araçlarında dijital aktivizm türlerini kullanarak kendi kamusal alanlarını yaratmaya çalışmaktadırlar. Öyle 
ki dijital olarak şekil değiştiren, yer ve zamana meydan okuyan toplumsal hareketlerin uzantısı dijital aktivizm eylemleri; özellikle dijital nesil olarak kabul edilen kuşakları derinden etkilemiş ve söz konusu nesillerde dijital aktivizm hareketlerine olan eğilimin arttığı görülmeye başlanmıştır.

\section{Sosyal Medya/ Sosyal Ağlar ve Dijital Aktivizm}

Çağımızın en etkileyici teknolojik buluşlarından biri şüphesiz ki internet olmuştur. Internet, toplumsal yaşamın önemli bir değişkeni olarak temel misyonunu yerine getirmekte ve işlevselliği nedeniyle bireyler için karşı konulmaz bir cazibe aracıdır. Sosyal medya ise söz konusu cazibenin önemli ölçüde yaratıldığı dijital bir sosyalleşme platformudur. Teknolojik, içerik ve yapısal olarak sürekli gelişim gösteren sosyal medya; zamansal farklılıkları yıkarak insanların her an her yerde her koşulda etkileşim halinde olmalarını ve sürekli görünür olmalarını sağlamaktadır. Jim Ellis ve Tom Trusott tarafından 1979 yılında Duke Üniversitesi'nde "Usunet" adı ile ilk sosyal medya platformu geliştirilmiştir. Dünyanın her yerinden erişimin sağlanabildiği bu platform mesaj panosu gibi kullanılmakta ve kullanıcılar birbirleriyle karşılıklı olarak mesaj paylaşabilmektedir (Kaplan ve Haenlein, 2010, s.61). Sosyal medya kavramı Guidewire Group ortaklarından olan Chris Shipley tarafından ilk kez kullanılmıştır. Kavram çevrimiçi (online) iletişim, destek, katılım ve bilgi alışverişi sağlayan tüm araçlar için kullanılmaktadır (Hayta, 2013, s.67). Sosyal medya iki farklı etkileşim türünden oluşmaktadır. Bunlar; es, zamanlı olan etkileşim ve es, zamanlı olmayan (asenkron) etkileşimdir. Es, zamanlı olan etkileşimde sosyal medya kullanıcıları birbirleri ile anlık olarak mesajlaşabilmektedir. Asenkron iletişim ise kullanıcıların profillerinde yer alan müzik, video ve fotoğraf paylaşımlarıdır (Tuten ve Solomon, 2015, s.3). Sosyal medyanın hizmetlerinden biri insanların birbirleriyle sanal bir ortamda buluşmasını sağlamaktır. Bunun için bireylere yarı açık veya tamamen açık bir profil oluşturmasına izin vererek, bu profillerle bireylerin diğer kişilerle bağlantı kurup, paylaşımlarda bulunmasını sağlar (Olgun, 2015, s.486). Sosyal medya; iletişim, etkileşim, işbirliği, bilgi paylaşımı vb. olanaklarını geniş bir yelpazede değerlendirilmesi gereken sosyal medya araçlarına borçludur. Facebook, Instagram, Twitter, Youtube, forumlar, wikiler, bloglar ve mikrobloglar sosyal medyanın önemli araçlarıdır. Öyle ki söz 
konusu sosyal ağlar; yalnızca karşılıklı etkileşimi ve bilgi aktarımını sağlamamakta; toplumsal hareketleri de çok ciddi ölçüde yönlendirebilmektedir.

Sosyal ağ kullanıcıları; çevresel, sosyal, politik ve ekonomik konularda savundukları ya da tepki gösterdikleri, haklı ya da haksız buldukları durumlar hakkında birbirlerini bilgilendirme, örgütlenmeyi sağlama ve eylemlerini dijital platformlarda gerçekleştirme gibi aktivist imkanlara sahiplerdir. Sosyal ağlarının giderek güç kazanması ile sosyal medyadaki aktivizm hareketlerinin yaygınlaşmasını beraberinde getirmiştir. Sosyal ağlara taşınan aktivist hareketler kitleleri harekete geçiren büyük bir güç haline gelmiştir. Sosyal medyanın bu etkileyici gücünün farkında olan sivil toplum kuruluşları da son yıllarda eylemlerini bu ortamlara taşımaktadırlar. Meydanlarda gerçekleştirilecek bir eylem öncesinde sosyal medyayı, insanların birbirleri ile haberleşmeleri ve örgütlenmeleri amacı ile etkili bir yol olarak kullanmaya başlamışlardır. Özellikle Twitter'ın 2007 yılında kurulması ile birlikte yaygınlaşmaya başlayan konu etiketleri (hashtag) ile, aynı görüşte olan insanların bir araya gelmeleri ve mesajlarını daha büyük kitlelere ulaştırmaları kolaylaşmıştır. Konu etiketleri, iletişim etkinliği sağlamak için bugün sosyal medyanın ayrılmaz bir parçası haline gelmiştir (livaport.com, 2017). Konuyla paralel olarak Gezi Parkı Direnişi hakkında Sayımer'in (2014) görüşleri ise şöyledir: Gezi Parkı Direnişi olarak Türkiye tarihine geçen ve farklı toplumsal dinamikleri barındıran kitlesel eylem, daha önce gerçekleşen farklı coğrafyalardaki toplumsal hareketlerde olduğu gibi bir birlik retoriğine sahip olmakla birlikte en baştan kendiliğindenlik özelliğini ortaya koymuştur. İlk önce bir grup çevre aktivistinin kentsel dönüşüme ve çevre tahribatına karşı İstanbul Gezi Parkında başlattıkları eylem, başta İstanbul olmak üzere giderek tüm ülkeye yayılmış, hareketin tüm dünyadan destek görmesiyle dünya çapında ses getirmiştir. Gezi Direnişi bir yanıyla yeni medya ortamlarını kullanarak sosyal ağlarda bir araya gelen ve örgütlenen, bir lidere ihtiyaç duymayan, özgürlükçü küresel Y kuşağ1 gençliğinin Türkiye'deki örneğini oluşturmuştur (s.108).

Gezi Parkı ile ilgili mesajların, videoların ve fotoğrafların sosyal paylaşım sitelerinde paylaşılması ile insanların organize olması ve insanların sosyal medya aracılı̆̆ı ile iletişim sağlayarak olaylar sırasında çekmiş oldukları görüntüleri, fotoğrafları paylaşarak diğer insanları olaylar hakkında bilgilendirmesidir. Yeni teknolojik gelişmeler ve internetin 
sunduğu imkanlar aracıllğıyla insanlar daha kolay örgütlenmekte ve bu örgütle eylemler/isyanlar devrim niteliği kazanmaktadır (Yeniçıktı, 2014, s.274). Bu direniş Türkiye'de ilk kez kendisine has bir eylem örgütlenme biçimi yaratmıştır. Özellikle gençlerin yeni iletişim teknolojileri aracılığıyla sosyal ağlarda bir araya gelmeleri ve yerleşik siyasi düzene karşı geliştirdikleri isyanı ifade etmek için kullandıkları terminolojiler toplumsal hareket eylemleri açısından farklı bir deneyim yaratmıştır (Sayımer, 2014, s.108).

Buraya kadar ki bilgiler kapsamında dijital aktivizmde kayda değer bir yere sahip olan sosyal medya, toplumsal hareketlerin ve oluşumların şekillendiği, ulusal ve uluslararası düzeyde yankı bulmasını sağladığı çeşitli fırsatlar yaratmaktadır. Sosyal medya evrenindeki sosyal ağlar; kullanıcılarına alternatif iletişim kurma biçimleri sunmaktadır. Kullanıcılara; her türlü toplumsal konularda bağımsız iradeleriyle fikirlerini paylaşmalarına, düşüncelerini savunmalarına imkan tanıyan, içerisinde tam anlamıla yeni bir dünya barındıran sosyal medya ve araçları; paylaşılmış dijital bir ruh kazanmıştır. Her geçen gün büyümekte olan sosyal medya içerisinde; inançlarını, değerlerini, tercihlerini herhangi bir engele takılmadan sınırsız bir ortamda paylaşan bireyler, dijital aktivizm dinamiklerini derinden etkilemişlerdir. Kuşkusuz sosyal medyayı en çok kullanan genç neslin, dijital aktivizm konusundaki etkin rolü de göz ardı edilememektedir.

\section{Teknoloji ve Dijital Nesiller: Y ve Z Kuşağı}

Dünya üzerinde, günümüz kadar birbiriyle yoğun iletişim içinde olunan bir dönem görülmemiştir. Bunun kök nedeni ise artan entegrasyon ve dijital dönüşümdür. Kültürel yapılarda, eğitimde, sağlıkta, satın alımda vb. birçok alanda yaşanan dijitalleşme, internetin gücü, pratikliği, her an her yerde olma imkanı tanıması gibi parametrelerden dolayı son yirmi yılda toplumların tüm iş yapış biçimleri radikal anlamda değişmiştir. Tüm bu değişimlere mental ve eylemsel olarak herkesin aynı biçimde, aynı oranda karşılık vermesi ve uyum sağlaması mümkün değildir; fakat bu durum yeni dijital dünyanın temposuna uygun, teknolojik dijital jargona hakim, günümüz dijital iletişimin uzmanları olarak kabul gören yeni kuşaklar 
için geçerli bir durum olmamaktadır. Dijitalin niteliksel açıdan yeni ve yenilikçi muazzam imkanları y ve $z$ kuşağı için yaşam biçimi haline dönüşmüştür. Bu bağlamda bahsi geçen kuşakların temel özelliklerine kısaca değinmekte fayda görülmektedir. Öncelikle kuşak kelimesi Yunan kökenli bir kelime olan "Genos" kelimesinden ortaya çıkmaktadır. Bu kelime biyolojik doğum olarak değerlendirilirken zaman açısından devamlı bir değişim olduğunu da vurgulamaktadır (Clarke, 2012, s.41). Kuşaklar yetişme tarzları ve içerisinde bulundukları ortam değişikliklerinden kaynaklanan farklılıklara sahiptirler. Bu farklılıklar; kuşaklar arasında hem karakter, hem çalışma yaşamları, hem de sosyal hayatlarında önemli ayrışmalar olduğunu ortaya koymaktadır (Yüksekbilgili, 2016). Bu çerçevede kuşaklar sosyolojik yönden belirli tarihlerde doğmuş bireylerin sosyalleşme sürecinde ortak politik, sosyal ve ekonomik olgulardan etkilenerek, ortak inanç, tutum, değer, sorumluluk ve beklentilere sahip gruplar haline gelmeleri olarak tanımlanmaktadır (Mannheim, 1970, s.164; Özer vd., 2013, s.125). Literatürde kuşaklar sessiz kuşak, bebek patlaması (Baby Boomers), X kuşağı, Y kuşağı ve Z kuşağı olmak üzere beş şekilde ele alınmaktadır (Williams ve Page, 2011); fakat bu kuşakların yas, aralıklarının belirlenmesinde net bir fikir birliği görülememektedir (Lissitsa ve Kol, 2016). Kuran'a göre (2018, s.18-82, 97-132) kuşaklar; 1927-1945 arası doğumlular Sessiz Kuşak; 1945-1964 arası doğumlular Bebek Bombardımanı Kuşağı; 1965-1979 arası doğanlar X kuşak; 1980-1999 arası doğanlar Y kuşak; 2000- 2008 arası doğanlar ise $Z$ kuşağı olarak sınıflandırılmaktadırlar. Bu çalışmada da mevcut sınıflandırma baz alınmış; $Y$ ve $Z$ kuşağı çalışmanın kapsamını oluşturduğu için söz konusu kuşaklar incelenmiştir.

$Y$ kuşağg; Milleniallar (Millennials), Dijital Kuşak (Digital Generation), Gelecek Kuşak (Generation Next), Sonrakiler (Nexters), www Kuşağ (www Generation), Net Kuşağı (Generation Next), Echo boomers, iGen gibi isimlerle adlandırılmaktadır (Jain ve Pant, 2012: s. 58; Çetin Aydın ve Başol, 2014, s. 3). 1980- 1999 yılları arasında doğan ve 7,5 milyarlık dünya nüfusunun yüzde 31'i, 81 milyonluk Türkiye nüfusunun ise yüzde 32'ni bu kuşak oluşturmaktadır (Kuran, 2018, s. 97). Y Kuşağı üyeleri teknoloji dünyasında büyüdüğünden ebeveynlerinden daha çok şey bilerek gelişmiş teknolojik bilgiler ışı̆̆ında her yere herkesin ulaşabileceği bir çağı başlatmışlardır (Meier vd., 2010, s. 68). Teknoloji ile yakından ilgili olan Y kuşağının (Bannon vd., 2011, s.63); yedi ayırt edici özelliği bulunmaktadır: 
özel, korunaklı, kendine güvenen, başarılı, takım odaklı, baskı altında ve gelenekseldir. Aynı zaman da bağımsız, özgür, otoriteye karşı, kurallar ile sinırlandırılmayan, mesai saatleri ile kısıtlanmayan, öz güvenli, bir an önce yükselmek isteyen, emir almaktan hoşlanmayan, dayatmalara karşı çıkan, inatçı ve direnişçi yapıları olan, sosyal medyada ve ortamlarda bulunmayı seven, kendi fikir ve istekleri doğrultusunda rahatça çatışmaya girebilen kişilerdir. (Bayraktar, 2017). Dolayısıyla esasında küreselleşme ve teknoloji, Y Kuşağının en belirgin kişilik özelliklerini ortaya çıkaran iki faktördür. Bu iki faktör daha fazla bilgiye erişim imkanını ortaya çkararak bu kuşak üyelerini buluşçu, yaratıcı, açık fikirli, girişimci ruhlu ve cesaretli olmalarını sağlamıştır (Kuyucu, 2015, s.188).

Y kuşağı insanı dijital dünyanın gelişimi sürecini çok yakından yaşamış ve teknolojinin gelişimini yetişmeleri süresince izlemiştir. Bu sebeple almış oldukları eğitim sebebiyle ve aynı anda internetin getirmiş olduğu veri ve bilgi birikimini çok üst düzeyde kullanan bir özelliği sahiptirler. Yetiştikleri süre içerisinde hızla gelişen Sosyal medya ağları, tabletler ve akıllı uygulamalar onları teknolojik olarak geliştirmiştir. The List of Millennial Characteristics, 2017)

Y kuşağı denilince akla ilk gelen kavram teknoloji olmaktadır. Bu kuşağa mensup kişiler sosyalleşmeye ve teknolojiye zaman ayırmalarıyla bilinmektedir. Y kuşağı bireyleri teknolojiyi çok yoğun bir şekilde kullanırlar. Y kuşağı bireyleri amaç veya görev dışında başkalarıyla iletişime geçmek amacıyla çevrimiçi ve çevrimdışı olarak sürekli bilgisayar kullanma eğiliminde olurlar (Keles, 2011, s.131). Y kuşağ bireylerinin farklı ülkelerde bulunmalarına rağmen benzer veya aynı sosyal ağlar ile internet sitelerini kullanmaları bu kuşağın "dünyanın ilk küresel kuşağı" olarak adlandırılmasina neden olmaktadır (McCrindle ve Wolfinger, 2009, s. 2).

Y kuşağ1; iletişim teknolojilerinde, sosyal ağlarda ve küreselleşmede çok hızlı bir gelişmeyi deneyimlemişlerdir (Park ve Gursoy, 2012). Bu kuşaktaki bireyleri şekillendiren bu hızlı gelişmeler, Y kuşağının sosyal medya kullanımını etkilemekte; sosyal medyayı eğlence, iletişim, sosyalleşme ve bilgi alma aracı olarak görmektedirler (Bolton vd., 2013). Ayrıca iletişim kurmak bu kuşağın sosyal medya kullanımının başlıca sebebidir (Palfrey ve Gasser, 2008). 
Z Kuşağı ise; Bu kuşağa i-kids (akıllı çocuklar), dijital yerliler (Prensky), net generation (ağ jenerasyonu) (Tapscott), digital born (dijital doğanlar) (Palfrey and Gasser), medya aileleri (Rideout ve Hammel), milenyum öğrencileri (Pedro) gibi isimler yakıştırılmıştır. (Selwyn 2009, s.364). Ayrıca Kristal Nesil, Internet Kuşağı veya I-Kuşak ve Google Kuşağ gibi birçok teknolojik isimden esinlenerek adlandırılmaktadır (Çetin ve Karalar, 2016, s.162). Prensky (2001) tarafından kullanılan dijital yerliler tanımı da bu kuşağı en iyi temsil eden kavramlardan biridir çünkü; bu kuşak dijital bir dünyada doğan ilk nesildir. Böylece çevrimiçi yaşamakta, bilgiye hızlı erişmekte, sanal olarak en sevdiği markalarla bütünleşmekte ve etkileşime girmektedirler (Bernstein, 2015). İstedikleri bilgiye yetenekleri ve teknoloji sayesinde çok hızlı ulaşan (Tas, vd., 2017, s.103) Z kuşağı; teknolojiye sınırsız erişimleri nedeniyle, teknik fırsatlar sayesinde bağlantılı, bilgi işlemlerinin hızından dolayı, hemen deneyimledikleri sosyal ortamlarda paylaşan "dijital okuryazar" olarak tanımlamaktadır (Oblinger ve Oblinger, 2005, s.2-7). Suskun kuşak olarak da isimlendirilen bu kuşak üyeleri; sosyal ağ ve yeni iletişim teknolojilerini profesyonel olarak kullanan bireylerden oluşmaktadır. Bu kuşağa suskun olarak adlandırılmasının sebebi olaylara olan tepkilerini yüksek seslerle veya fiziksel güçle değil, iletişim araçları ile ifade etmeleridir. $\mathrm{Bu}$ kuşak üyeleri birçok teknolojik imkanla birlikte büyüdükleri için Z Kuşağı aynı anda okuma, izleme ve konuşabilme yeteneklerine sahiptir. (Metin ve Kızıldağ, 2017, s.345).

$\mathrm{Bu}$ kuşağın en önemli özelliklerinden biri, modern dijital dünyada "yerliler" olarak doğdukları gerçeğidir (Greenfield, 2009) İlk günlerinden bu yana teknoloji dünyası ile çevrelenmişlerdir ve bu nedenle yaşadıkları, sosyalleştikleri, bilgiyi algıladıkları ve karar aldıkları yollar diğer nesillerdekinden tamamen farklıdır (Artemova, 2018, s.8). Merriman'a (2015) göre diğer belirgin özellikleri ise şöyledir: yeni teknolojilere olan yüksek ilgi, kullanım kolaylı̆̆ı konusunda ısrar, güvende hissetme arzusu, karşılaştıkları gerçekliklerden geçici olarak kaçma arzusudur.

Araştırmacılar Z kuşağını toplumsal adalet meseleleriyle ilgili, teknolojik açıdan donanımlı, yüksek derecede eğitimli ve yaratıcı düşünceye sahip bir kuşak olarak tanımlamaktadır (Trevino, 2018). Z Kuşağı üyeleri, cinsiyet eşitliği ve iklim değişikliği bilinci çağında doğup büyüyen en küresel ve çok kültürlü kuşaklardır. Sparks ve Honey (2015, s.46) tarafından yayımlanan raporda belirtildiği üzere bu nedenle $\mathrm{Z}$ 
Kuşağı üyeleri önceki nesillerden farklı olarak sosyal sorumluluk bilinci yüksek olan, küresel meselelere karşı ilgili ve dünyayı değiştirmeye kararlı bir nesildir. Z kuşağı, bilgiye erişimde ya da insanlarla bağlantıda sınır tanımamakta ve coğrafi sınırlar bir engel teşkil etmemektedir. Çünkü neredeyse her şey çevrimiçi olarak bulunabilmekte ve dünyanın her yerinden insanlarla bağlantı birkaç saniye içinde yapılabilmektedir. Sparks ve Honey $(2015$, s.46) de kolaylıkla ulaşılan çevrimiçi ortamların Z kuşağ üyelerinin, çeşitli kişileri deneme, ilgi alanı seçme, farklı topluluklara katılma ve ufkunu genişletme özgürlüğüne sahip olduğunu ileri sürmektedirler.

Z kuşağı; doğuştan sosyal medyalıdır. Çünkü bu kuşaktakilerin çoğunun bebeklik fotoğrafları ebeveynleri tarafından arkadaşları ve akrabaları ile paylaşılmış ve böylece doğduklarından itibaren dijital ayak izleri oluşmaya başlamıştır (Cioletti, 2018). Sosyal medya üzerindeki diğer kişilerin görüşlerini de çok değer vermektedirler; ayrıca güncel olaylar, sosyal, ekonomik, politik olaylar hakkında görüş bildirme noktasında son derece duyarlılardır (Prakash ve Rai, 2017).

Y ve Z kuşağının karakteristik özellikleri ile sosyal medya ilişkileri dikkate alındığında; tarihsel açıdan birbirlerine yakın kuşaklar olmalarına karşın belirgin bazı farklılıkları olduğunu belirtmek doğru olacaktır. Özellikle Y kuşağı internet çağına yeni geçildiği dönemi temsil ederken; $Z$ kuşağ1 teknoloji ve internet ile dünyaya gözünü açmıştır. Dolayısıyla $Y$ kuşağ1 için teknolojiyi iyi kullanan; $Z$ kuşağ1 için de ileri derecede teknolojiyi kullanan, internetin olmadığı bir dünyayı hayal edemeyecek kadar teknolojiye ve dijital gelişmelere bağımlı kuşak olarak özetlemek mümkündür. Ancak her iki kuşağın sosyal medya ve internet kullanımı noktasında benzerlikler taşıdığı söylenebilmektedir.

\section{Araştırmanın Amacı}

Y ve $Z$ kuşağının dijital odaklı yaşamları; dijital ortamlardaki yeni toplumsal hareketlere olan bakış açıları, düşünce biçimleri, ilgileri, yorumlamaları önemli ölçüde dikkat çekmektedir. Dikkat çekici bu unsurdan hareketle şekillenen bu çalışmanın temel amacı teknolojiden, dijital girdi ve çıtılardan oldukça etkilenen, dijitali yaşam biçimi haline dönüştürmüş, 
sosyal medya ve araçlarının birincil kullanıcıları olan Y ve Z kuşaklarının; dijital aktivizme ilişkin farkındalık ve anlayış düzeylerini tespit etmektir.

Bu temel amacın yanı sıra; $Y$ ve $Z$ kuşaklarının sosyal ağları kullanma düzeyleri ile dijital aktivizm kapsamında değerlendirilebilecek konulara ilişkin sosyal ağlardaki tavırlar, katılım dereceleri, kendilerini dijital aktivist olarak değerlendirip değerlendirmediklerini keşfetmek çalışmanın amaçları arasındadır. Çalışmada elde edilen sonuçlardan hareketle $Y$ ve $Z$ kuşaklarının dijital aktivizm hakkındaki bilgi, düşünce, tutum benzerlikleri ve farklılıkları incelenerek, karşılaştırma yapılması hedeflenmektedir.

\section{Araştırmanın Önemi}

Araştırmanın kapsamını günümüzün en dijital güruhu olarak kabul edilen ve sosyal ağları ciddi oranda kullanan $Y$ ve Z kuşağı üzerinde tasarlanması çalışmayı önemli hale getirmektedir. Dijital aktivizm olgusunun ise mevcut kuşaklarla birleştirilmesi ve iki kuşağın da teknoloji kuşağı olmasına karşın aralarında dijital aktivizm hakkında olası görüş farklılıklarının tespiti, farkındalık ve anlayış düzeylerinin karşılaştırılmalı şekilde yorumlanması gibi gerekçeler orta ve uzun vadede bu alanda yapılacak çalışmalara etkin bir uzgörü kazandırılabilmesi açısından önem arz ettiği düşünülmektedir.

\section{Araştırmanın Yöntemi}

Çalışmada nicel araştırma yöntemi tercih edilmiştir. Veri toplama aracı olarak anket formu hazırlanırken; Brodock vd.'nin (2009) dijital aktivizme ilişkin sunduğu 2009 yılı raporundaki sorular dikkate alınmış; araştırmanın amaçları gözetilerek oluşturulan soru ve seçeneklerde birtakım değişiklikler gerçekleştirilmiştir. Toplam 19 sorudan oluşan anket formunda; katılımcıların demografik bilgileri, internet ve sosyal medya kullanım düzeyleri ve kullanım amaçlar ile dijital aktivizm hakkındaki bilgileri, görüş ve düşüncelerine ilişkin sorulara yer verilmiştir. Bazı sorular ise birden çok seçeneğin işaretlenebileceği şekilde tasarlanmıştır. Basılı şekilde hazırlanan anket formu katılımcılara elden dağıtılmıştır. Araştırma kapsaminda elde edilen veriler SPSS (Statistical Packege for Social Science) for Windows 25.0 programı kullanılarak analiz edilmiştir 


\section{Araştırmanın Evren ve Örneklemi ile Sınırlılıkları}

Araştırmanın evrenini; sosyal ağları kullanan $Y$ ve $Z$ kuşakları oluşturmaktadır. Zaman ve maliyet kısıtlılıklarından ötürü İzmir ili örneklem olarak seçilmiş ve spesifik olarak mevcut kuşaklar hedef alındığ 1 için ağırlıklı olarak üniversite öğrencileri örneklemi oluşturmuştur. Ayrıca araştırmaya toplamda 148 kişi katılım göstermiştir. Bu durum araştırmanın sinırlılıkları içerisinde de yerini almaktadır. Araştırma; ankete katılanların sorulara dürüst cevaplar verdiğini varsaymaktadır. Öte yandan araştırma Kasım-Aralık 2019'da elde edilen bilgi ve bulgularla sınırlıdır.

\section{Araştırma Verilerinin Analizi}

Veriler, anlamlılık $\mathrm{p}<0,05$ düzeyinde değerlendirilmiştir. Verileri değerlendirirken tanımlayıcı istatistik metotlarından sayı, yüzde, ortalama ve standart sapmadan yararlanılmıştır. Nicel değişkenlerin analizi için ise Mann Whitney U testi kullanılmıştır. Kategorik değişkenler arasındaki ilişkiyi analiz edebilmek için Pearson Ki kare analizi yapılmıştır.

Tablo 1. Katılımcıların Demografik Bilgileri Dă̆ılımı

\begin{tabular}{lccc}
\hline Özellik & & Sayı & (\%) \\
\hline Cinsiyet & Kadın & 61 & 41,2 \\
& Erkek & 87 & 58,8 \\
\hline Kuşak & $1980-1999(\mathrm{Y})$ & 67 & 45,3 \\
& $2000-2004(\mathrm{Z})$ & 81 & 54,7 \\
\hline Eğitim durumu & Ön lisans okuyor & 143 & 96,5 \\
& Üniversite + & 5 & 3,5 \\
\hline Meslek & Öğrenci & 143 & 96,5 \\
& Memur & 5 & 3,5 \\
\hline \multicolumn{4}{c}{} \\
& Gelir: Öğrenci: $741,12 \pm 47,28$ \\
\end{tabular}

Araştırmaya katılan bireylerin \%41,2'si kadın, \%58,8'i erkektir; \%45,3'ü Y kuşağı, \%54,7'si Z kuşağıdır. Bireylerin \%96,5'i ön lisans öğrenimine devam etmektedir (hala öğrenci), \%3,5'i ise üniversite ve daha üstünde bir eğitim kurumundan mezun olmuştur (memurdur). Öğrencilerin ortalama 
gelirleri 741,12 TL; memurların gelir ortalamaları ise 3.940,00 TL olduğu tespit edilmiştir.

Tablo 2. Katılımcıların Sosyal Ağları Kullanma Sıklıkları Hakkındaki Dağılım

\begin{tabular}{lccc}
\hline Özellik & & Sayı & $\mathbf{( \% )}$ \\
\hline Sosyal ağ kullanımı & Evet & 146 & 98,6 \\
& Hayır & 2 & 1,4 \\
\hline Sosyal ağ hesabını & Günde 1 kez & 9 & 6,1 \\
kontrol etme sıklığı & Günde bir kaç kez & 59 & 40,1 \\
& Haftada birkaç & 2 & 1,4 \\
& Ayda birkaç & 1 & 0,7 \\
\hline
\end{tabular}

Tablo-2'e göre; katılımcıların \%98,6'sı sosyal ă̆ kullanmaktadır ve $\% 40,1$ 'i günde birkaç kez, \%51,7'si sürekli sosyal ağ hesabını kontrol etmektedir.

Tablo 3. Katılımcıların Aktivizm Çă̆rışımları, Bilgileri ve Dijital Aktivist Olup/Olmadıkları Hakkındaki Değerlendirmelerine İlişkin Dağılımı

\begin{tabular}{lccc}
\hline & Çağrışımlar & Say1 & $\mathbf{( \% )}$ \\
\hline Aktivizm kavramının & Eylemcilik & 37 & 25,0 \\
yarattı̆̆ı çağrışım & Etkincilik & 50 & 33,8 \\
& Devrim & 6 & 4,1 \\
& Toplumsal hareketler & 42 & 28,4 \\
& Boykot & 3 & 2,0 \\
& Gösteri & 2 & 1,4 \\
& Direnç & 5 & 3,4 \\
& Eylemcilik & 37 & 25,0 \\
\hline Dijital aktivizm & Evet & 48 & 32,4 \\
kavramını daha önce & Hayır & 64 & 43,2 \\
duyup /duymadıları & Hatırlamıyorum & 36 & 24,3 \\
\hline Dijital aktivist olduğunu & Evet & 52 & 35,1 \\
düşünme & Hayır & 96 & 64,9 \\
\hline
\end{tabular}

Tablo-3'e göre; aktivizm kavramının katılımcılarda çağrıştırdığı kavramlar incelendiğinde, \%33,8'i etkincilik, \%28,4'ü toplumsal hareketler, \%25'i eylemcilik olduğunu belirtmiştir. Katılımcıların \% 4'ü ise devrim olarak çağrışım yarattığını ifade etmişlerdir. Ayrıca katılımcıların \% 43,2'i dijital aktivizm kavramını daha önce duymamışken, \%32,4' ü kavramı, daha önce duyduklarını ifade etmişlerdir. Katılımcıların \% 35,1'i ise kendini dijital aktivist olarak değerlendirmektedir. 
Tablo 4. Sosyal Ağları Kullanım Amaçları İle Kuşaklar Arasındaki İlişki

\begin{tabular}{|c|c|c|c|c|c|}
\hline \multirow{2}{*}{\multicolumn{2}{|c|}{ Özellik }} & \multicolumn{2}{|c|}{ Y kuşağı } & \multicolumn{2}{|c|}{ Z kuşağı } \\
\hline & & say1 & $(\%)$ & say1 & $(\%)$ \\
\hline \multirow{10}{*}{ 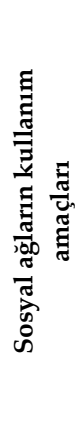 } & $\begin{array}{l}\text { Arkadaş ve yakınlarınızın ne yaptığından haber } \\
\text { olmak }\end{array}$ & 54 & 43,5 & 70 & 56,5 \\
\hline & Güncel haber ve olaylardan haberdar olmak & 61 & 44,5 & 76 & 55,5 \\
\hline & Komik ve eğlenceli içerikleri bulmak & 55 & 46,6 & 63 & 53,4 \\
\hline & İlgilendiğiniz konuları tartışmak & 34 & 41,5 & 48 & 58,5 \\
\hline & Diğerleri ile fotoğraf ve video paylaşmak & 34 & 43,0 & 45 & 57,0 \\
\hline & Başkaları ile iletişim halinde olmak & 32 & 35,6 & 58 & 64,4 \\
\hline & Yeni insanlarla tanışmak & 17 & 37,8 & 28 & 62,2 \\
\hline & $\begin{array}{l}\text { Gündelik hayatınızda yaptıklarınızın detaylarını } \\
\text { paylaşmak }\end{array}$ & 7 & 30,4 & 16 & 69,6 \\
\hline & Bir ideoloji veya toplumsal hareketi desteklemek & 24 & 46,2 & 28 & 53,8 \\
\hline & Politik içerikler için & 19 & 54,3 & 16 & 45,7 \\
\hline
\end{tabular}

Katılımcıların sosyal ağlarda geçirdikleri sürenin, kuşaklar arasında farklılık gösterip göstermediğini tespit edebilmek için Mann Whitney U testi yapılmıştır. Sonuçlar incelendiğinde, sosyal medyada geçirilen süre kuşaklara göre farklılık göstermektedir $(\mathrm{p}<0,05)$. $Z$ kuşağının sosyal medyada daha fazla zaman geçirdiği tespit edilmiştir. Tablo-4'de; Z kuşağının \%69,6'nın sosyal ağları gündelik hayatlarında yaptıklarını detaylı paylaşmak için kullandığını belirtirken, Y kuşağının \%46,6'1 sosyal ağları komik ve eğlenceli içerikleri bulmak için kullandığını belirtmiştir. Öte yandan $Z$ kuşağının \%53,8'i, Y kuşağının da \%46,2'i sosyal ağları; bir ideoloji veya toplumsal hareketi desteklemek amaçlı kullandıklarını belirtmişlerdir.

Tablo 5. Bilinen Aktivistler ve Kuruluşar ile Kuşaklar Arasındaki İlişki

\begin{tabular}{|c|c|c|c|c|c|c|}
\hline \multirow{2}{*}{\multicolumn{3}{|c|}{ Özellik }} & \multicolumn{2}{|c|}{ Y kuşağı } & \multicolumn{2}{|c|}{ Z kuşağı } \\
\hline & & & sayı & $(\%)$ & sayı & $(\%)$ \\
\hline \multirow{4}{*}{\multicolumn{2}{|c|}{$\begin{array}{l}\text { Tarihte aktivist } \\
\text { olarak bilinen } \\
\text { isimler }\end{array}$}} & Mahatma Gandhi & 36 & 49,3 & 48 & 53,3 \\
\hline & & Martin Luther King & 42 & 46,7 & 37 & 50,7 \\
\hline & & Cesar Chavez & 9 & 50,0 & 9 & 50,0 \\
\hline & & John Lenon & 26 & 51,0 & 25 & 49,0 \\
\hline \multirow{2}{*}{\multicolumn{2}{|c|}{ Özellik }} & & \multicolumn{2}{|c|}{ Y kuşağı } & \multicolumn{2}{|c|}{ Z kuşağı } \\
\hline & & & sayı & $(\%)$ & sayı & $(\%)$ \\
\hline \multirow{6}{*}{ 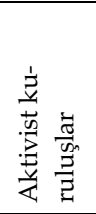 } & \multicolumn{2}{|c|}{ Greenpeace } & 45 & 48,9 & 47 & 51,1 \\
\hline & \multicolumn{2}{|c|}{ Dünya Doğayı Koruma Vakfı (WWF) } & 49 & 47,1 & 55 & 52,9 \\
\hline & \multicolumn{2}{|c|}{ Sea Shepherd } & 5 & 33,3 & 10 & 66,7 \\
\hline & \multicolumn{2}{|c|}{ Uluslararası Af Örgütü } & 20 & 62,5 & 12 & 37,5 \\
\hline & \multicolumn{2}{|c|}{ Kadın Dayanışma Vakfı } & 45 & 47,9 & 49 & 52,1 \\
\hline & \multicolumn{2}{|c|}{ Humane Society } & 15 & 48,4 & 16 & 51,6 \\
\hline
\end{tabular}


Tablo-5'de; katılımclların 4 dijital aktivist ve 6 kuruluş isimlerini bilenlerin sayısının kuşaklar arasında farklılık gösterip göstermediğini tespit edebilmek için Mann Whitney $U$ testi yapılmıştır. Tarihteki aktivist isimlerini bilenlerin sayısının kuşaklara göre değişmediği; ancak aktivist kuruluşların isimlerinin farklılık gösterdiği tespit edilmiştir. Y kuşağının $Z$ kuşağından daha fazla kuruluş ismi bildiği tespit edilmiştir. Tarihteki aktivistlere; Y kuşağının \%51 John Lenon'u, Z kuşağının \%53,3'ü Mahatma Gandhi'i adını vermiştir. Y ve Z kuşakları; aktivist kuruluşların büyük bir kısmını bildiklerini belirtmişlerdir.

Tablo 6. Sosyal Ağlarda Dijital Aktivizm Konuları İle Kuşaklar Arasındaki İlişki

\begin{tabular}{|c|c|c|c|c|c|}
\hline \multirow[b]{2}{*}{ Özellik } & & \multicolumn{2}{|c|}{ Y kuşağı } & \multicolumn{2}{|c|}{ Z kuşağı } \\
\hline & & sayı & $(\%)$ & sayı & $(\%)$ \\
\hline \multirow{6}{*}{ 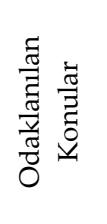 } & İnsan Hakları & 53 & 46,9 & 60 & 53,1 \\
\hline & Hayvan Hakları & 51 & 46,8 & 58 & 53,2 \\
\hline & Kadın Hakları & 49 & 46,7 & 56 & 53,3 \\
\hline & Çocuk Hakları & 51 & 49,0 & 53 & 51,0 \\
\hline & LGBT hakları & 19 & 57,6 & 14 & 42,4 \\
\hline & Cevre Hakları & 47 & 51,1 & 45 & 48,9 \\
\hline
\end{tabular}

Tablo-6' da katılımcıların verileri bireysel satır bazlı ele alınmıştır. 53 Y kuşağı, 60 Z kuşağı katılımcıları insan hakları konusuna odaklandıklarını belirtmişlerdir.

Tablo-7'e göre; dijital aktivist olduğunu düşünme durumu ile kuşaklar arasındaki ilişkiyi belirleyebilmek için yapılan Pearson Ki sonuçları incelendiğinde ilişkinin olmadığ 2,380 ki kare değeridir. $P$ (olasılık) değeri ise $0,123^{\prime}$ dir. $Y$ kuşağının $\% 41,8^{\prime} i$, $\mathrm{Z}$ kuşağının ise \%29,6'1 dijital aktivist olduğunu düşünmektedir.

Tablo 7. Dijital Aktivist Olduğunu Düşünme Durumu İle Kuşaklar Arasındaki Ilişkiler

\begin{tabular}{|c|c|c|c|c|c|}
\hline & & & \multicolumn{2}{|c|}{ Kuşak } & \multirow[t]{2}{*}{ Toplam } \\
\hline & & & Y & Z & \\
\hline \multirow{4}{*}{$\begin{array}{c}\text { Dijital aktivist } \\
\text { olduğunuzu } \\
\text { düşünüyor musu- } \\
\text { nuz? }\end{array}$} & Evet & sayı(\%) & $28(41,8)$ & $24(29,6)$ & $52(35,1)$ \\
\hline & Hayır & $\mathrm{n}(\%)$ & $39(58,2)$ & $57(70,4)$ & $96(64,9)$ \\
\hline & & \multicolumn{4}{|c|}{$X^{2}$ değeri: 2,380} \\
\hline & & \multicolumn{3}{|c|}{ p değeri:0,123 } & \\
\hline
\end{tabular}


Tablo 8. Dijital Aktivizme Dair Sosyal Ağlarda Yapılanlar İle Kuşaklar İlişkisi

\begin{tabular}{|c|c|c|c|c|c|}
\hline \multirow{2}{*}{\multicolumn{2}{|c|}{ Özellik }} & \multicolumn{2}{|c|}{ Y kuşağı } & \multicolumn{2}{|c|}{ Z kuşağ1 } \\
\hline & & sayı & $(\%)$ & sayı & $(\%)$ \\
\hline \multirow{11}{*}{ 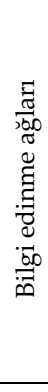 } & Facebook & 20 & 38,5 & 32 & 61,5 \\
\hline & Twitter & 35 & 43,2 & 46 & 56,8 \\
\hline & Youtube & 43 & 48,9 & 45 & 51,1 \\
\hline & Instagram & 48 & 46,2 & 56 & 53,8 \\
\hline & Bloglar & 13 & 43,3 & 17 & 56,7 \\
\hline & Linkedin & 9 & 60,0 & 6 & 40,0 \\
\hline & Pinterest & 8 & 57,1 & 6 & 42,9 \\
\hline & Flickr & 2 & 66,7 & 1 & 33,3 \\
\hline & Snapchat & 3 & 30,0 & 7 & 70,0 \\
\hline & Reddit & 4 & 30,8 & 9 & 69,2 \\
\hline & Katıllmcı sözlükler & 30 & 47,6 & 33 & 52,4 \\
\hline \multirow{2}{*}{\multicolumn{2}{|c|}{ Özellik }} & \multicolumn{2}{|c|}{ Y kuşağ1 } & \multicolumn{2}{|c|}{ Z kuşağ } \\
\hline & & Sayı & $(\%)$ & Say1 & $(\%)$ \\
\hline \multirow{12}{*}{ 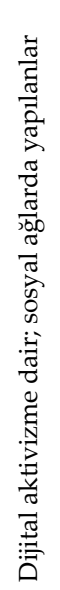 } & İnsan, hayvan, çevre, çocuk vb. ile ilgili toplumsal & 22 & 45,8 & 26 & 54,2 \\
\hline & konular hakkında içerik oluşturuyor ve & & & & \\
\hline & Sivil toplum kuruluşu veya şirketlerin toplumsal & 40 & 50,0 & 40 & 50,0 \\
\hline & $\begin{array}{l}\text { konulara ilişkin paylaşımlarını takip ediyorum veya } \\
\text { beğeniyorum. }\end{array}$ & & & & \\
\hline & Başkalarının yorumlarını kendi sayfama ekliyorum. & 14 & 45,2 & 17 & 54,8 \\
\hline & $\begin{array}{l}\text { Tanıdığım herkese konuyla ilgili bilgiler gönderi- } \\
\text { yorum }\end{array}$ & 14 & 37,8 & 23 & 62,2 \\
\hline & $\begin{array}{l}\text { Karar alıcılar ile iletişime geçerek; üzerlerinde baskı } \\
\text { oluşturmaya çalışıyorum }\end{array}$ & 7 & 53,8 & 6 & 46,2 \\
\hline & Gündem oluşturmak için bir hashtag oluşturuyorum. & 13 & 54,2 & 11 & 45,8 \\
\hline & Dijital materyal dağıtıyorum & 3 & 75,0 & 1 & 25,0 \\
\hline & Boykot ediyorum & 12 & 63,2 & 7 & 36,8 \\
\hline & İşitsel bilgi yayınlıyorum. & 4 & 44,4 & 5 & 55,6 \\
\hline & $\begin{array}{l}\text { Toplumsal bir mesele adına eylem veya çabayı bel- } \\
\text { gelendirmeye çalıșıyor veya paylașıyorum }\end{array}$ & 13 & 54,2 & 11 & 45,8 \\
\hline
\end{tabular}

Tablo-8'e göre; 56 Z kuşağı, 48 Y kuşağı Instagram'dan; 46 Z kuşağı, 35 Y kuşağı Twitter' dan dijital aktivizm ile ilgili konuları takip ettiklerini belirtmişlerdir. Ayrıca kuşaklara göre konuların sayısı değişmezken; bilgi edinme ağlarının sayısı farklılık göstermektedir. $40 \mathrm{Y}$ ve $\mathrm{Z}$ kuşağı; sivil toplum kuruluşu veya şirketlerin toplumsal konulara ilişkin paylaşımlarını takip ettiklerini veya beğendiklerini belirtmişlerdir. $26 \mathrm{Z}$ kuşağı, 22 Y kuşağı insan, hayvan, çevre, çocuk vb. ile ilgili toplumsal konular hakkında içerik oluşturduklarını ve paylaştıklarını da belirtmişlerdir. 
Tablo 9. Dijital Aktivist Kavramını Daha Önceden Duyma Durumu İle Kuşaklar Arasındaki İlişkiler

\begin{tabular}{|c|c|c|c|c|c|}
\hline & & & \multicolumn{2}{|c|}{ Kuşak } & \multirow[t]{2}{*}{ Toplam } \\
\hline & & & $\mathrm{Y}$ & Z & \\
\hline Anketten önce & Evet & say1 $(\%)$ & $26(38,8)$ & $22(27,2)$ & $48(32,4)$ \\
\hline "dijital aktivizm" & Hayır & say1 $(\%)$ & $26(38,8)$ & $38(46,9)$ & $64(43,2)$ \\
\hline $\begin{array}{l}\text { kavramını hiç } \\
\text { duydunuz mu? }\end{array}$ & $\begin{array}{l}\text { Hatırlamiyor } \\
\text { um }\end{array}$ & sayi $(\%)$ & $15(22,4)$ & $21(25,9)$ & $36(24,3)$ \\
\hline \multicolumn{6}{|c|}{$\begin{array}{c}X^{2} \text { değeri: } 2,279 \\
\text { p değeri: } 0,320\end{array}$} \\
\hline
\end{tabular}

Tablo-9'a göre; daha önceden dijital aktivizm kavramını duyma durumu ile kuşaklar arasındaki ilişkiyi belirleyebilmek için yapılan Pearson Ki sonuçları incelendiğinde ilişkinin olmadığ Kuşakların \%32,2'i dijital aktivizm kavramını daha önce duyduklarını; $\% 43,2 ' i$ ise duymadıklarını belirtmişlerdir.

\section{Sonuç ve Değerlendirme}

Çalışma kapsamında dijital dönemin önemli temsilcileri olan $\mathrm{Y}$ ve $\mathrm{Z}$ kuşağının dijital aktivizm konusundaki farkındalık düzeyleri, kavrama ilişkin bilgi ve düşünceleri, aktivizm konusunda sosyal ağları ne amaçla, ne ölçüde kullandıklarına ilişkin verilere ulaşılmaya çalışılmıştır. Araştırmanın büyük bir çoğunluğunu üniversite öğrencileri oluşturmaktadır. \%45,3'ü Y kuşağı iken, \%54,7'si Z kuşağıdır; Y ve Z kuşağının dengeli olmasına özen gösterilmiştir.

Gerçekleştirilen anket çalışması ile; $\mathrm{Y}$ ve $\mathrm{Z}$ kuşağının sosyal ağları kullanım düzeyleri, terim olarak aktivizm ve dijital aktivizmin ne ifade ettiği, tarihteki aktivistlerden ve aktivist kuruluşlardan hangilerini bildikleri, daha çok hangi aktivist konulara ilgileri olduğu; sosyal ağları bu konularla ilgili ne şekilde kullanıp kullanmadıkları ve daha önce dijital aktivizm kavramını duyup duymadıkları hakkında elde edilen veriler incelenmiştir. Yapılan frekans ve çapraz analizlerin koyduğu sonuçlar doğrultusundan; kuşakların \%98,6'nın sosyal ağları kullandıkları görülmüştür ve kuşakların \%40,1'i günde birkaç kez, \%51,7'si sürekli sosyal ağ hesabını kontrol etmektedir. Burada dikkat çeken sonuç; $Z$ kuşağının sosyal medyada daha fazla zaman geçiriyor olmasıdır. Bu durumu $Z$ kuşağının; dijital dünyanın getirileri ile büyümesine ve dijitalleşmenin $Z$ kuşağı için 
bir yaşam biçimi olması ile açıklanabilmektedir. Elde edilen veriler $\mathrm{Y}$ ve $\mathrm{Z}$ kuşaklarının internet ve yeni iletişim teknolojilerini kullanım oranları hakkında da önemli bilgiler vermektedir.

$\mathrm{Z}$ kuşağının \%69,6'nın sosyal ağları gündelik hayatlarında yaptıklarını detaylı paylaşmak için kullandığını belirtirken, Y kuşağının \%46,6'ı sosyal ağları komik ve eğlenceli içerikleri bulmak için kullandığını belirtmiştir. Bu durum kuşakların sosyal ağları ağırlıklı olarak ne amaçla kullandıklarını da göstermektedir. Ancak; Z kuşağının \%53,8'i, Y kuşağının da \%46,2'i sosyal ağlarl; bir ideoloji veya toplumsal hareketi desteklemek amaçlı kullandıklarını belirtmişlerdir. Dolayısıyla kuşakların toplumsal hareket konuları hakkında da sosyal ağları kullandıkları görülmektedir.

Aktivizm kavramının $\mathrm{Y}$ ve $\mathrm{Z}$ kuşağında yarattı̆̆ çağrışımlara ilişkin elde edilen veri sonuçları incelendiğinde; toplam kuşak sayısının $\% 33,8^{\prime}$ nin etkincilik kavramını, \%28,4'nün ise toplumsal hareket kavramını çağrıştırdığını belirtmişlerdir. Kuşaklarda; aktivizm kavramına dair alan yazınında kavramsallaşmış terimlerin çağrışması oldukça dikkat çekicidir.

$\mathrm{Y}$ ve $\mathrm{Z}$ kuşağının dijital aktivizm kavramın daha önce duyup duymadıkları hakkında elde edilen veriler sonucunda; kuşakların \%32,4'ü kavramı duyduğunu, \%43,2'i daha önce kavramı duymadıklarını belirtmişlerdir. Bu durum dijital aktivizmin kavram olarak tarihi geçmişinin çok uzak olmaması ve bu nedenle yaygın kullanılmayışı ile açıklanabilmektedir.

Çalışmanın en dikkat çekici sonuçlarından biri; dijital kuşak olarak kabul edilen ve zamanlarının kayda değer bir kısmını dijital platformlarda (sosyal ağlarda) geçiren $Y$ ve $Z$ kuşağının toplam \%64,9'nun kendini dijital aktivist olarak görmemesidir. Bu durum kuşakların dijital aktivist kavramını daha önce duymadıklarına bağlanabilmektedir.

Kuşakların bildikleri aktivistlerin sayısına ilişkin bariz bir farklılık görülmemiştir. Y kuşağının \%51 John Lenon'u, Z kuşağının \%53,3’ü Mahatma Gandhi'i adını vermiştir. Aktivist kuruluşlar hakkında da Y kuşağının $\mathrm{Z}$ kuşağından daha fazla kuruluş bildiği sonucuna varılmıştır. Bilinen kuruluşlar daha çok Greenpeace ile Dünya Doğayı Koruma Vakfı (WWF)'dır.

Kuşakların dijital aktivizm kapsamında; sosyal ağlar üzerinde daha çok hangi konular üzerinde durduklarına ilişkin elde edilen veri sonuçları da dikkat çekicidir. Zira Y kuşağı katılımclarının büyük bir çoğunluğu; sosyal 
ağlarda insan, hayvan, çocuk hakları konularına daha önem verdiklerini belirtirken; Z kuşağı katılımcıları; insan, hayvan, kadın hakları konularına daha fazla eğildiklerini belirtmişlerdir. Öte yandan Y kuşağının \%46,2'i , Z kuşağının ise \%53,8'i Instagram'dan dijital aktivizm ile ilgili konuları takip ettiklerini belirtmişlerdir. Dolayısıyla kuşakların insan, çocuk, kadın, çevre vb. konularda Instagram'ı daha etkin kullandıklarını söylemek mümkündür. Ayrıca kuşaklara göre konuların sayısı değişmezken; bilgi edinme ağlarının sayısı farklılık göstermiştir.

Çalışmanın önemli bir noktasını $Y$ ve Z kuşağının sosyal ağlarda dijital aktivizm kapsamında neler yaptıklarını tespit etmek olmuştur. Öyle ki iki kuşak da sosyal ağlarda; en çok sivil toplum kuruluşu veya şirketlerin toplumsal konulara ilişkin paylaşımlarını takip ettiklerini veya beğendiklerini belirtmişlerdir. İkinci seçenek olarak da insan, hayvan, çevre, çocuk vb. ile ilgili toplumsal konular hakkında içerik oluşturduklarını ve paylaştıklarını belirtmişlerdir. Dolayısıyla kuşakların dijital aktivizm hakkında sosyal ağlar üzerindeki tutumlarının benzerlik gösterdiği çıkarımına varmak mümkündür. $\mathrm{Bu}$ sonuç $\mathrm{Y}$ ve $\mathrm{Z}$ kuşağı hakkında ortaya atılan slaktivizm/kliktivizm; yani $\mathrm{Y}$ ve $\mathrm{Z}$ kuşağının dijital bir eylemi durdukları yerden destekleme yaklaşımı ile hareket ettikleri yönünde akıllarda soru işareti bırakmaktadırlar. 


\title{
EXTENDED ABSTRACT
}

\section{A Significant Destination in Social Activation: A Research on Awareness of $Y$ and Z Generation Regarding Digital Activism and Its Dynamics in Social Networks}

\author{
* \\ Gonca Köse \\ Dokuz Eylül University
}

In an era when daily life is transferred to virtual platform and everything involves digital, the social movements also get its share from such conditions. Representing the congregate of people for a particular purpose in relation with the aspects bearing on the society such as human, animal and environmental rights etc., the concept of social movement is originated from collective attitudes and behaviors created in digital platforms today. The concept of activism related to social movement gives way to digital activism. Digital activism is to do an activist act and expression to stir the individuals in digital environment by means of various communication technologies. In fact, the generation which is identified with the concept of digital activism at the most and experiences the digitalization deeply is certainly $\mathrm{Y}$ generation, accepted as technology generation, and the generation which experiences the dynamics of digital era up to the hilt is $\mathrm{Z}$ generation, named as digital habitants.

$\mathrm{Y}$ and $\mathrm{Z}$ generations' digital-oriented lives, point of view on new social movements in digital environment, opinion styles, interests and comments draw attention in a significant level. The main purpose of this study starting out from this attractive factor is to determine the awareness and perception levels of $Y$ and $Z$ generations, which are affected quietly by digital inputs and output, and converted to a digital lifestyle and primary users of social media and tools, in relation with digital activism. In addition to this main purpose, the following aspects are taken place in the purpose of the study: $\mathrm{Y}$ and $\mathrm{Z}$ generations' social network activity levels and attitudes in social networks in relation with the matters which may be evaluated in the scope of digital activism, participation levels and determination whether they 
identify themselves as digital activist. In the study, quantitative research method was preferred. While questionnaire form was prepared as data collection tool, the questions in the report presented by Brodock et.al. (2009) in 2009 in relation with digital activism were considered, and some questions and options were amended by minding the purpose of the research. In the questionnaire form consisting of 19 questions totally, there were questions related to participants' demographical data, internet and social media usage levels, usage tools, information about digital activism and opinions and views. The data obtained in the scope of research was analyzed by using SPSS (Statistical Package for Social Science) for Windows 25.0 Program. Population of the research was constituted by $\mathrm{Y}$ and $\mathrm{Z}$ generations using social networks. Due to the restriction of time and cost, province Izmir was selected as sample, and university student sample was prepared mainly as the current generations was aimed specifically. Moreover, 148 people participated into the research totally. Majority of the research was constituted by university students. While $45,3 \%$ was $\mathrm{Y}$ generation, $54,7 \%$ was $\mathrm{Z}$ generation. By means of the questionnaire, findings were acquired about $\mathrm{Y}$ and $\mathrm{Z}$ generations' social network usage levels, what activism and digital activism meant terminologically, which activist and activist organizations they knew, on what activist subjects they were interested, and in which type they used the social networks and whether they heard the concept of digital activism before. As a result of the frequency and cross-analysis, it was observed that $98,6 \%$ of the generations used social networks and that $40,1 \%$ of the generations checked their social network accounts several times in a day and $51,7 \%$ checked them constantly. The result which draw attention here is that; $Z$ generation spends more time in social media. This situation may be explained thus and so $Z$ generation is being raised with gaining of the digital world and digitalization becomes a life style for $\mathrm{Z}$ generation. The data obtained has provided significant information related to use ratios of internet and new communication Technologies by $\mathrm{Y}$ and $\mathrm{Z}$ generations. While the $69,6 \%$ of $Z$ generation states that they use social networks in order to share things in detail they did in their daily lives, the $46,6 \%$ of $Y$ generation uses social networks to find comic and funny contents. This circumstance indicates for what purpose generations use social networks predominantly. However; the $53,8 \%$ of $\mathrm{Z}$ generation and the $46,2 \%$ of $\mathrm{Y}$ generation 
have indicated that they use social networks in order to support any ideology or social movement. Therefore, it is seen that the generations use social networks regarding social movement matters.

When the data results of the associations of the notion activism created in $\mathrm{Y}$ and $\mathrm{Z}$ generations is examined; the $33,8 \%$ of generation number in total evokes the notion activism, the $28,4 \%$ of them associates the notion of social movement. In generations; the association of the conceptualised terms in literature of the activism notion is quite remarkable. One of the most attention grabbing results of the study is that the $64,9 \%$ of $Y$ and $\mathrm{Z}$ generations who are accepted as digital generation and who spend a part of their significant time in digital platforms (social networks) do not see themselves as activist. This situation may be connected to the fact that they may not have heard the notion of digital activist before. The data which is acquired regarding what topics the generations focus on social networks more within the scope of digital activism is also remarkable.

Likewise, while most participants of $Y$ generation attach importance to human, animal, child rights in social networks; $Z$ generation states that they keen on subjects such as human, animal, women rights more. On the other hand, the $46,2 \%$ of $Y$ generation and $53,8 \%$ of $Z$ generation stated that they follow the topics related to digital activism on Instagram. Hence, it is possible to deduce that the attitudes of the generations on social networks regarding digital activism show similarity. This result put a question mark in the minds regarding the fact that slacktivism/clicktivism put forward related to $Y$ and $Z$ generations which means that $Y$ and $Z$ generations act with a supporting approach for a digital action on their places.

\section{Kaynakça / References}

Andreas, M. K. ve Michael, H. (2010). The users of the world- the challenges and opportunities of social media. Paris: Business Horizons.

Artemova, A. (2018). Engaging generation $\mathrm{Z}$ through social media marketing. Licence Thesis, South- Eastern Finland University of Applied Sciences.

Bannon, S., Ford, K., ve Meltzer, L. (2011). Understanding millennials in the workplace. CPA Journal, 81(11): 61-65.

Bayraktar, N. (2017). "Y kuşağı nedir? Özellikleri nelerdir?." 25.11.2019 tarihinde https://paratic.com/y-kusagi-nedir- ozellikleri-nelerdir/ adresinden erişilmiştir. 
Bernstein, R. (2015). Move over millennials e here comes Gen Z. Ad age. 20.11.2019 tarihinde http://adage.com/article/cmo-strategy/movemillennials-gen-z/296577// adresinden erişilmiştir.

Bolton, R., Hoefnagels A., Migchels, N., Kabadayi, S., Gruber T., Loureiro Y., ve Solnet, D. (2013). Understanding gen $Y$ and their use of social media: A review and research agenda. Journal of Service Management, 24 (3), $245-267$.

Boschele, A., Öztürk, F. ve Çetin, Ö. (2017). Dijital iletişim teknolojileri ve toplumsal hareketler bağlamında hacktivizm. Üsküdar University Journal of Social Sciences, 5, 429- 452.

Brodock, K., Mary, J. ve Timo, Z. (2009). Digital activism survey report DigiActive. 21.10.2019 tarihinde https://katebrodock.com/digital-activism-survey-results- ae2a5b16d944 / adresinden erişilmiştir.

Browman, S., Willis, C. (2003). We media: How audiences are shaping the future of news and information. The Media Center at the American Press Institute. 25.11.2019 tarihinde http://www.hypergene.net/wemedia/weblog.php adresinden erişilmiştir.

Cioletti, A. (2018). Hi there, gen Z! Nice to meet you. 21.10.2019 tarihinde https://www.licenseglobal.com/magazine-article/trendwatch-hithere-gen- z-nice-meet-you. adresinden erişilmiştir.

Clarke, B. P. (2012). Din sosyolojisi. Çev., İ. Çapcioğlu. İstanbul: İmge Kitabevi.

Crossley, N. (2002). Making sense of social movements. Buckingham, Philadelphia: Open University Press.

Çayır, F. (2018). Dijital bir hak mücadelesi olarak video aktivizm ve video aktivistlerin yaşadığı hukuki sorunlar. G. Şener ve N. Gider Işıkman (der.). Video Aktivizmde Kavramlar, Sorunlar, Uygulamalar içinde(s.5586). Ankara: Um: ag Vakfı Yayınları.

Çayır, K. (2016). Yeni sosyal hareketler. İstanbul: Kaknüs Yayınları.

Çetin A. G. ve Başol, O. (2014). X ve Y kuşağı: Çalışmanın anlamında bir değişme var mı?. Ejovoc (Electronic Journal of Vocational Colleges), 4(4),1-15.

Çetin, C. ve Karalar, S. (2016). X, Y ve Z kuşağı öğrencilerin çok yönlü ve sınırsız kariyer algıları üzerine bir araştırma. Yönetim Bilimleri Dergisi, 14 (28), 157-197.

Çımrın, K. F. (2010). Yeni toplumsal hareketler ve kentsel yaşam. Gümüşhane Üniversitesi Sosyal Bilimler Elektronik Dergisi, 2, 45-58. 
Çoban, S. (2009). Yeni toplumsal hareketler ve iktidar sorunu- Yeni toplumsal hareketler: Küreselleşme çağında toplumsal muhalefet içinde. İstanbul: Kalkedon Yayınları.

C,osskun, K. M. (2007). Demokrasi teorileri ve toplumsal hareketler. Ankara: Dipnot Yayınları.

Demiroğlu, T. E. (2014). Yeni toplumsal hareketler: Bir literatür taraması. Marmara Üniversitesi Siyasal Bilimler Dergisi, 2(1), 133-144.

Duran, R. (2003). Yurttaş gazeteciliği, gazetecilik ve habercilik. İstanbul: IPS İletişim Vakfı Yayınları.

Form, W. ve Craig, J. (2013). Toplumsal hareketler ve toplumsal değişim. Çev., Olcay Sevimli, Ankara: Phoenix Yayınevi.

Giddens, A. (2000). Sosyoloji. Çev., Hüseyin Özel ve Cemal Güzel. Ankara: Ayraç Yayınları.

Greenfield, S. (2009). Id: The quest for meaning in the 21st century. UK: Hachette. Hayta, A. B.(2013). A study on the of effects of social media on young consumers buying behaviors. European Journal of Research on Education, 65-74.

Ipadmin. (2017.) Aktivizm ve sosyal medya. 09.11.2019 tarihinde https://www.livaport.com/aktivizm-sosyal-medya/. Adresinden erişilmiştir.

Işık, G. (2015). Nükleer santral karşıtı bir toplumsal hareketin analizi-sanaldan sokă̆a toplumsal hareketler. Ankara: Nobel Yayıncilik.

Jain, V. ve Pant, S. (2012). Navigating generation y for effective mobile marketing in India: A conceptual framework. International Journal of Mobile Marketing, 7(3), 56-65.

Joyce, M. (2010). Digital activism decoded the new mechanics of change. International Debate Education Association.

Keles, N. H. (2011). Y kuşağ1 çalışanlarının motivasyon profillerinin belirlenmesine yönelik bir araştırma. Organizasyon ve Yönetim Bilimleri Dergisi, 3(2), 129-139.

Kırık, M. A. ve Özcan, A. (2014). Bir dijital aktivizm örneği: Akıllı ağ çeteleri (Smart Mobs). AJIT-e: Online Academic Journal of Information Techno$\log y, 5(14), 61-78$.

Kuran, E. (2018). Telgraftan tablete- Türkiye'nin 5 kuşă̆ına bakış. İstanbul: Destek Yayınları.

Kuyucu, M. (2015). Y kuşağının radyo dinleme doyumları üzerine bir araştırma. Akademik Sosyal Araştırmalar Dergisi, 3(21), 186-202.

Lissitsa, S. ve Kol, O. (2016). Generation X vs. Generation Y - A decade of online shopping. Journal of Retailing and Consumer Services, 31, 304-312. 
Lucky, A. (2017). The list of millennial characteristics. 09.11.2019 tarihinde http://luckyattitude.co.uk/millennial- characteristics/ adresinden erişilmiştir.

Mannheim, K. (1970). The problem of generations. Psychoanalytic Review. 57(3), 378-404.

Mccrindle, M. ve Wolfinger, E. (2009). The ABC of XYZ: Understanding the global generations. Australia: McCrindle Research Pty Ltd.

Meier, J, Austin, S. ve Crocker, M. (2010). Generation Y in the workforce: Managerial challenges. The Journal of Human Resource and Adult Learning. $6(1), 68-78$.

Melucci, A. (2016). Çă̆daş hareketlerin sembolik meydan okuması. Çev., Kenan Çayır. İstanbul: Kaknüs Yayınları.

Merriman, M. (2015). What if the next big disruptor isn't a what but a who?." 12.11.2019 tarihinde https://www.ey.com/Publication/vwLUAssets/EY-what-if-the-next-big- disruptor-isnt-a-what-but-awho/\$File/EY-what-if-the-next-big-disruptor-isnt-a- what-but-awho.pdf. adresinden erişilmiştir.

Metin, S. ve Kızıldağ, D. (2017). X ve Y kuşaklarının kariyer beklentilerinin farklılaşması: Otomotiv sektöründe bir araştırma. Mustafa Kemal Üniversitesi Sosyal Bilimler Enstitü̈üDergisi, 14 (40), 340-363.

Morozov, E. (2017). Facebook ve Twitter sadece devrimcilerin gittiği yerlerdir. Çev., Filiz Aydoğan. İstanbul: Der Yayınları.

Morozov, E. (2007). How can activists and NGO"S benefit from new media. 02.11.2019 tarihinde https://www.slideshare.net adresinden erişilmiştir.

Oblinger, D. ve Oblinger, L. J. (2005). Educating the net generation. Educause.

Olgun, B. (2015). Sosyal medyanın tüketici satın alma davranışları üzerindeki etkisi. Gümüşhane Üniversitesi Sosyal Bilimler Elektronik Dergisi, 4(12), 484- 507.

Özer, S. P, Eriş, D. E., Nezcan, O:, ve Özmen, T. (2013). Kuşakların farklılaşan iş değerlerine ilişkin emik bir araştırma. Dumlupınar Üniversitesi Sosyal Bilimler Dergisi. 38, 123-142.

Palfrey, J. ve Gasser, U. (2008). Born digital: Understanding the first generation of digital natives. New York: Basic Book.

Park, J., ve Gürsoy, D. (2012). Generation effects on work engagement among U.S. hotel employees. International Journal of Hospitality Management, 31(4), 1195- 1202. 
Prakash, G., ve Rai, J. (2017). The generation Z and their social media usage: A review and a research outline. Global Journal of Enterprise Information System. 9(2), 110- 122.

Prensky, M. (2001). Digital natives and digital immigrants. On the Horizon MCB University Press, 9(5), 1-6.

Randy, S. (1996). The activist's handbook: A primer for the 1990s and beyond. University of California Press.

Ruffin, O. (2004). Hacktivism, from here to there. 01.12.2019 tarihinde http://www.cultdeadcow.com/cDc_files/cDc-0384.php. adresinden erişilmiştir.

Sayımer, İ. (2014). Yeni medya ortamlarında ağlar oluşturan toplumsal hareket deneyimleri. Elektronik Mesleki Gelişim ve Araştırma Dergisi, 2(2), 97-112.

Selwyn, N. (2009). The digital native- myth and reality. Emerald Insight, 1(4), 364-379.

Sert, Y. N. (2012). Online aktivizm araçları yoluyla oluşturulan etkilerin metafor kullanılarak açıklanması örnek olay incelemesi: İnternetime dokunma eylemi. Akdeniz Üniversitesi İletişim Fakültesi Dergisi, 17, 126140.

Shaffer J.T. (2004). The media and civic engagement. 07.11.2019 tarihinde http://www.pewcenter.org/doingcj/speeches/s grantmakers.html adresinden erişilmiştir.

Sivitanides, M. (2011). The era of digital activism. Conference for Information Systems Applied Research.

Sparks ve Honey Culture Forecast. (2015). Generation Z 2025: The final generation. 11.11.2019 tarihinde https://www.slideshare.net/sparksandhoney/gen-z-2025-the-final-generation-preview/99-GEN Z 2025METHODOLOGYFor Gen $Z$ adresinden erişilmiştir.

Tas, H. Y., Demirdöğmez, M., ve Küçükoğlu, M. (2017). Geleceğimiz olan Z kuşağının çalışma hayatına muhtemel etkileri. OPUS-Uluslararası Toplum Araştırmaları Dergisi, 7(7), 1033-1048.

Tilly, C. (2008). Toplumsal hareketler 1768-2004. Çev., O. Düz. İstanbul: Babil Yayınları.

Touraine, A. (1999). Toplumdan toplumsal harekete. Çev., Kenan Çayır. İstanbul: Kaknüs Yayınları.

Trevino, G. N. (2018). The arrival of generation Z on college campuses. Doctoral dissertation, University of The Incarnate Word. 
Turhan, G., ve Okcu, M. (2018). Siyasette dijital yerliler ve göçmenler. Ankara: Gece Kitaplı̆̆ı.

Tuten, L. T., ve Solomon, R. M. (2015). Social media marketing. Londra: Sage.

Uçkan, Ö. (2012). Dijital aktivizm ne kadar etkili ? 02.11.2019 tarihinde https://spotdergi.wordpress.com adresinden erişilmiştir

Williams, C. K., ve Page, A. R. (2011). Marketing to the generations. Journal of Behavioral Studies in Business, 3, 11-17.

Yeğen, C. (2014). Dijital aktivizmin bir türü olarak hacktivizm ve redhack. EJournal of Intermedia. 1(1), 118-132.

Yeğen, C. (2015). Bir dijital aktivizm biçimi olarak slaktivizm: Change.org Örneği. Karadeniz Teknik Üniversitesi İletişim Araştırmaları Dergisi, 85-108.

Yeniçıtı, T. N. (2014). İletişimsel eylem ve facebook: Gezi parkı olaylarında sosyal medyanın gücü. Selçuk İletişim Dergisi, 8(2), 263-284.

Yüksekbilgili, Z. (2016). Tüketici karar verme tarzlarının kuşaklara göre değerlendirilmesi. Elektronik Sosyal Bilimler Dergisi, 15(59), 1392-1402.

\section{Kaynakça Bilgisi / Citation Information}

Köse, G. (2020). Toplumsal hareketlenmede önemli bir durak: Sosyal ağlarda dijital aktivizm ve dinamiklerine ilişkin $Y$ ve $Z$ kuşağının farkındalıkları üzerine bir araştırma. OPUS-Uluslararası Toplum Araştırmaları Dergisi, 15(22), 1255-1288. DOI: 10.26466/opus.665241 